\title{
Financial Planning and Business Performance: Evidence from Private Sector of Uzbekistan
}

\author{
Khasan Akhmedov \\ Department of Finance, Tashkent Financial Institute, 60 A, Amir Temur street, 100000, Tashkent, Uzbekistan
}

\begin{abstract}
Prudent financial planning is a clue for sustainability, viability and activeness of an enterprise in market and business environment. Flexibility and relevance of financial analysis, forecast and expectations ensures longer stay and access to the market in any conditions. In transition and developing economies, role of financial planning is central as the economy and business environment are under reforms and development. This article examines the relevance of financial planning in the context of a business environment of a transition economy and provides recommendations for further improvement.
\end{abstract}

Keywords: financial planning, business environment, budgeting, forecasting, Uzbekistan.

\section{Introduction}

Organizations depend on finance to arm the business with accurate, timely insight and planning strategies to help the business succeed (Krishnan, 2015). Appropriate and realistic business expectations, their flexibility, achievability, consistency with market and business environments can be reached by proper planning and forecasting. As firms seek profit, financial planning gains the central role in business performance, control and monitoring. In today's practice, diverse tools and methods of financial planning are exploited: from pure theoretical to advanced practical. Scientists have been proving the relevance of different econometric equations and models of financial planning, while experts of business development agencies advice to have a realistic approach with real market scenarios and business conditions and not to stick to formulas and models. Since existing discrepancies between positions of academia and business rounds are quite harsh, financial planning models of theoretical roots reflect large-scale analysis of economic condition in a country.

Managing business performance in today's complex and rapidly changing business climate is crucial for any organization's short-term and long-term success. Financial planning, a key component of managing and driving business performance, continues to be of limited value and mired with conservatism for many organizations (PwC, 2010). As a firm works for generating profit for investors, it can be said that the firm's economic impact is more important than social one, and firm's performance is measured with how it is profitable. Financial stability, profitability and development of organizations mean the business performance and, in turn, it requires an exact, precise and growth-oriented plan for long-term firm development. Structural weaknesses in economy may be avoided if a plan is complete and wide-scope. However, development strategy of a firm cannot reflect the whole roadmap of improving the financial profile in different periods of time. Therefore, financial planning for different time frames and specific conditions facilitates the smooth functioning of cost and revenue management tools at firm level.

After global financial crisis, many corporations and large individual firms began making more pessimistic financial scenarios due to high market fragility and less profitability in international markets. It had a direct influence on financial planning practices and procedures in an economy at large with high level probability of spreading crossing the borders. Business environment of developing and transition economies faced further discrepancies in financial activeness and its forecasting. Because subsidiaries of multinational enterprises experienced significantly painful financial shocks from the global market and local economic conditions. Financial planning and performance analysis became even more important to keep functioning and avoid financial difficulties in a harsh economic circumstance. As a representative of transition economic grouping, Uzbekistan has been supporting the modern business practices despite abovementioned implications of global financial crisis and gradual economic transition. Business environment of the economy introduced key elements of international business practices and structures. However, performance analysis and financial planning still needs a development support from practical standpoint due to removal processes of communistic laziness and adoption of market psychology to people's mind. This article examines the best practices of financial planning and evaluates their adaptability to Uzbekistan's practice.

\section{Literature Review}

Financial planning is an old but regularly updated topic of scientific research. It has been more practical than theoretical because of its direct application in real economic conditions. Therefore, findings of economic research often do not match with the views of practitioners and business rounds. However, several econometric and statistic models of financial planning are actively used by companies in planning, forecasting and uncertainty assessment. Kosy and Wise (1984) investigated the financial planning models further and developed 
the quantitative relationships among activities, measures and their future consequences in financial performance of a firms. Maranas et al. (1997) found that global optimization model can be clue for long term financial planning problems through dynamically balanced approach. Mulvey and Shetty (2000) proposed a framework for modeling significant financial planning problems based on multi-stage optimization under uncertainty Xu (2004) examines the financial planning and firm's financial capacity through stochastic programming approach and found a strong linkage among market uncertainty, financial and production planning.

\section{Financial Planning in a Dynamic Business Environment}

Along with other private sector development initiatives, the business environment affects the performance of private enterprises in both the formal and informal economies (DCED, 2008). In developing and transition economies, business environment regularly changes structurally with new elements of market economy. Reforms and removals of former economic systems often create different conditions and consequences in business environment. In some cases, as observed after global financial crisis, many businesses faced serious financial problems derived from systemic hazards from economic downturn in their economies. Business crisis led to fiscal crisis which eventually caused for total blockage of business sector rescue policy by the government due to poor fiscal condition and vanishing demand in all markets. Some experts said that financial crisis would not affect too strong if firms made more prudent and flexible financial plans. Flexibility of financial framework may ensure longer play in market and may cut long-term effects of financial crisis. Serious and solid plans and forecasts of revenue and financial profile, different sources of funding and overwhelmingly active position in financial markets made firms live in a dying market of advanced economies. Shortening market demand and financial market disorder hit the firms with a doubled punch of bankruptcy.

Dynamic business environments are of developing and transition economies. They are opening up for new horizons of business opportunities and promising sectors. Developed economies had already formed the business atmosphere at favourable level, so they are not dynamic at all. A dynamic business environment is evergrowing in size and scope, but it needs a plenty of components of business conduct and regulatory tools of developed countries (Figure 1). At first, as firms seek profit, a dynamic business environment has to adopt the best practices of business finance and financial management for successful functioning.

Figure 1. Business Environment and Its Elements

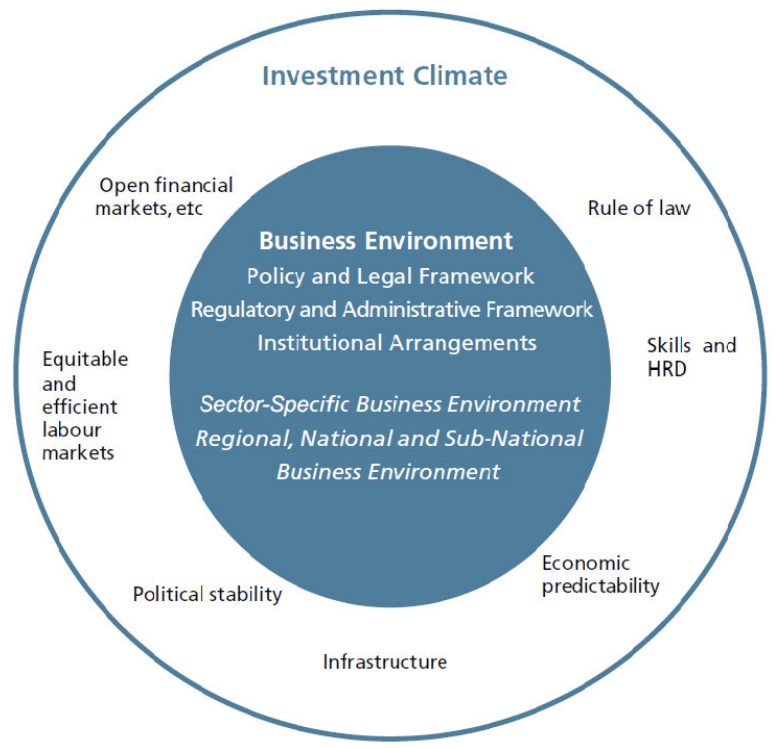

Source: DCED, 2008

All dynamic business environments are remarkable with unpredictable economic conditions owing to rapid changes in business sector. Most of them in the planet are export-oriented which shows that they are vulnerable to external shocks.

\section{Financial Planning in Growing Private Sector of Uzbekistan}

In some economies, private sector is awakening, ownership structures and corporate relations are still spreading among business rounds. But in former Soviet economies, the private sector is nearly reborn: it is in formation process from the very bases. Seven decades of communistic regime with socialist economic system had eliminated the even fundamentals of private ownership and business from people's mind. Now business psychology and market principles are actively learnt and absorbed, new businesses are being created. 
Considering the initial steps were successful, and small and medium sized enterprises remained as the main stakeholder in national output, production and market supply, it can be said that Uzbekistan has an extending business environment. However, a sound and favorable business climate cannot be created in two decades of economic transition and reforms. Nowadays some weaknesses in business practices are becoming more evident, as international markets began tightening. Especially in business relations, market players are lacking the basics of business conduct, structure and finance. In parallel with rapid economic growth and developing business environment, firms should adopt international practices in financial management and corporate relations. Financial planning, budgeting and forecasting practices are crucial for all enterprises to stay profitable and stable in the market.

Uzbek economy is in transition and growth, which requires more prudential financial planning for business sustainability and viability in a rapidly changing market condition. In case of transition, financial planning is a matter of more complex action than traditional revenue-expenditure expectations of an enterprise. Financial planning must focus on the flexibility and relevance of two components: budgeting and forecasting. The optimal level of detail to be utilized for financial budgeting and forecasting has surfaced as a passionate topic for debate for many organizations (PwC, 2011).

Figure 2. Prudential Financial Planning
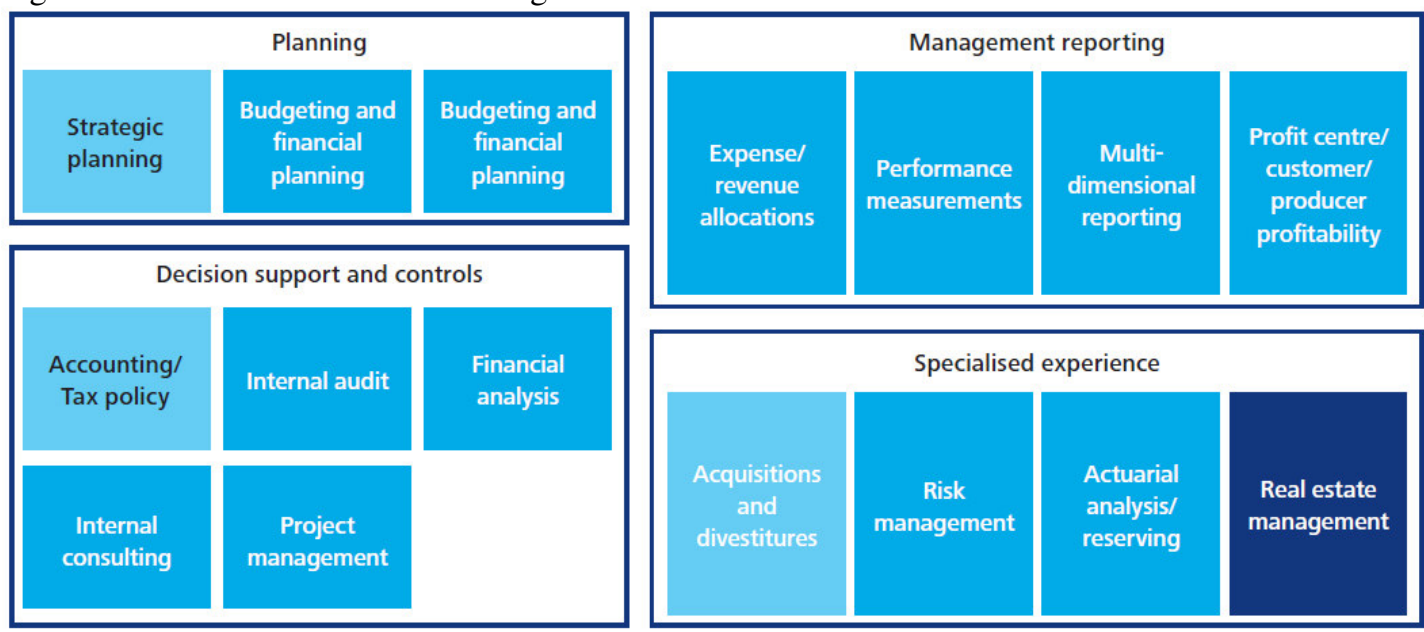

Source: Deloitte Research, 2011

Financial planning sometimes causes frustrations for business owners and stakeholders, if it does not consider the objectives and targets of the strategic plan for future extension. In some cases financial plans of enterprises does not consider the clear and complete forecasts of economic condition. Future financial performance of a firm should include the forecasts of external economic variables such as inflation, foreign exchange and economic growth etc.

\section{Conclusion}

Private sector in Uzbekistan has been expanding since the launch of privatization policy. It is driving the economic growth and development in the economy. Establishment of new businesses, foreign enterprises and opening of new sectors of production have brought novice terms to business lexicon and new assets to performance portfolio. Prudential financial planning is one of widespread terms which found an update in Uzbek private sector. Previous practices are enriching with new components from international experience. However, it needs further developments in following areas of actions:

1. Forecasting of external market indicators (economic growth, inflation, foreign exchange) should be reflected in financial planning, budgeting and strategic plans.

2. Management reporting reflects the clear observation of financial performance and condition of an enterprise. It should be run in compulsory and ongoing bases.

3. Financial officers should make financial plans which ensure the proximity to both strategic plans and real economic condition.

\section{References}

1. Baker, H. and Ricciardi, v. (2015). Understanding Behavioral Aspects of Financial Planning and Investing. Journal of Financial Planning. Vol.28, No. 3, pp. 22-26.

2. Garner et al. (1997). Ernnst \& Young's Financial Planning Essentials. John Wiley \& Sons, Inc. 
3. Kallberg, J., White, R. and Ziemba, W. (1982). Short Term Financial Planning under Uncertainty. Management Science. 28(6), pp. 670-682.

4. KPMG (2014). Big data comes of age in FP\&A- Financial Planning, Budgeting \& Forecasting. KPMG's Financial Management Services. USA.

5. Maranas, C. et al. (1997). Solving Long-Term Financial Planning Problems via Global Optimization. Journal of Economic Dynamics and Control. No.21. pp. 1405-1425.

6. Mulvey, J. and Shetty, B. (2004). Financial Planning via Multi-Stage Stochastic Optimization. Computers \& Operations Research. Vol. 31. 1-20.

7. PwC. (2011). Financial Planning: Realizing the Value of Budgeting and Forecasting. CFO Research Services Publications. CFO Publishing.

8. $\mathrm{Xu}, \mathrm{X}$. and Birge, J. (2006). Equity Valuation, Production, and Financial Planning: A Stochastic Programming Approach. Naval Research Logistics. 53(7), pp. 641-55. 